\title{
Agro By-product Feedstuffs and Livestock Management Systems for Rural Livelihoods in Cross River State
}

\author{
A.A. Ayuk \\ Department of Animal Science, University of Calabar, P.M.B. 1115, Calabar, Nigeria \\ Tel: 234-080-3270-7002Ｅ-mail: yinsaj@yahoo.com \\ G.A. Kalio (Corresponding author) \\ Department of Agricultural Science, Rivers State University of Education, Ndele Campus \\ P.M.B. 5047, Port Harcourt, Nigeria \\ Tel: 234-080-3300-0589Ｅ-mail: ag.kalio@yahoo.com \\ L.N. Agwunobi \\ Department of Animal Science, University of Calabar, P.M.B. 1115, Calabar, Nigeria \\ Tel: 234-080-3580-4162 E-mail: link_leonard@yahoo.com \\ B.I. Okon \\ Department of Animal Science, University of Calabar, P.M.B. 1115, Calabar, Nigeria \\ Tel: 234-081-3882-5162 E-mail: basseyokonedu@yahoo.com
}

Received: September 19, 2010 Accepted: October 12, 2010 doi:10.5539/jas.v3n2p191

\begin{abstract}
The study was conducted to ascertain the potential feedstuffs available for livestock management in three senatorial districts of Cross River State, Nigeria. A total of 192 structured questionnaires were administered to sole livestock and crop-livestock farmers in 24 villages at eight per village. At collection only 176 were retrieved from the respondents representing the farm households. Data were analyzed using descriptive statistics. Results showed that the livestock farmers comprising both livestock and crop-livestock farmers were made of males $(58.0 \%)$ and females $(42.0 \%)$ within the age bracket of $34-44$ years out of which $56.2 \%$ were illiterates and $43.8 \%$ literate. Crop-livestock farmers $(86.4 \%)$ dominated the farming operations, managing their livestock under the semi-intensive and extensive systems. The crop-livestock system was worthwhile since farmers recycled agro by-products as feedstuffs for an average of 3 goats and 2 sheep per household. This system will help to improve farmers' income and their livelihoods.
\end{abstract}

Keywords: Agro by-products, Crop-livestock systems, Farmers' livelihood

\section{Introduction}

The average protein supply in Nigeria per head per day is about 56.6g (Bawa, et al., 2007), a value that is considerably low compared to the $65 \mathrm{~g}$ per head per day recommended by FAO (1988). This scenario is aggravated by the increasing unavailability of the conventional feedstuffs. As a result low protein intake especially among the rural poor in the developing countries resulting in poor nutritional status becomes eminent (FAO, 1988).

The high cost of conventional feeds ( Edache et al., 2007) and the scarcity of energy and proteins in forages during the dry season (Adegbola et al., 1988) for monogastrics and ruminants, respectively has resulted in a marked decrease in voluntary feed intake, digestibility and subsequent weight losses among these animals. This has aroused several interests in the search for cheaper feedstuffs as substitutes. 
Agro by-products are one of such feed materials that could be utilized. These feedstuffs which are derived in integrated crop-livestock systems (Thornton et al., 2002; Kristjanson et al., 2002) have been described by El-Nouby (1991) as those materials obtained other than the main product for which the crop is cultivated. They include On-farm by-products or crop residues (straws, stubbles, leaves, tops, etc) (El-Nouby, 1991) and Agro-Industrial by-products (AIBP) which are obtained from crop processing: cassava peels, cocoyam peels, yam peels, rice bran, cowpea husk, rice husk, maize husk, banana peels and plantain peels (El-Nouby, 1991; Adesomu, 1987). Similarly, recent trends in animal nutrition in Nigeria based on the principles of minimum input and efficient feed utilization have focused attention on these farm by-products especially for the feeding of small ruminants (Fesae et al., 2007).

It is however observed that several of these feed resources abound in the rural villages of Cross River State that have not been optimally utilized for livestock feeding in small-holder livestock farming systems. It is therefore suggested that the identification and inclusion of these groups of feedstuffs into the feeding systems in the area could be a strategy to improve the feeding of animals amidst highly priced conventional feeds and the unpredicted seasonal fluctuations of forages during the dry season. The objective of this study is therefore, to identify agro by-products available for livestock feeding as well as ascertain the animal rearing practices that could improve farmers' livelihood in Cross River State.

\section{Materials and Methods}

Cross River State comprises of three senatorial districts: Northern, Central and Southern senatorial districts. Two local Government Areas each were selected at random from these senatorial districts and four villages each making a total of 24 villages was also randomly selected for the study (Table 1). The study was carried out through the use of structured questionnaires. A total of 192 questionnaires were used for the study and they were randomly distributed to respondents' in households of eight per village. Out of this number of questionnaires distributed only 176 was retrieved from the respondents (Table 1). Data collected from the survey were analyzed using descriptive statistics.

\section{Results}

Table 1 shows explicitly the various senatorial districts, their local government areas, the villages sampled and how the questionnaires used to elicit information from respondents were distributed for the study.

Table 2 shows the general information on the respondents expressed in percentages. It revealed that both males and females engaged in livestock farming (sole livestock and crop-livestock farming) but more males (102; $58.0 \%)$ were involved than their female counterparts $(74 ; 42.0 \%)$. Rearing of livestock was common among adults of 35-44 years age bracket representing $44.9 \%$ of the total respondents. Similarly, the farming population interviewed during the survey comprised of $56.2 \%$ illiterates and $43.8 \%$ literates (at least could read and write). Majority of the farmers $(86.4 \%)$ were involved in crop-livestock farming in the villages that were investigated. About $51.7 \%$ of the respondents who kept their livestock do this under the semi-intensive system of management, while $42.6 \%$ and $5.7 \%$ practiced extensive and intensive systems respectively.

Table 3 shows the farm animals, pattern/mode of ownership and agro by-products for animal feeding in different Local government areas of Cross River State. The types of livestock kept by the respondents in order of preference were goats, fowl, sheep, ducks, pigs and cattle. The study further revealed that a greater proportion $(54.55 \%)$ of the keepers of these livestock kept them in mixed populations, while $45.45 \%$ kept them in single populations. Similarly, $72.73 \%$ of the respondents reported that they were sole owners of their farm animals, whereas $27.27 \%$ own them on contractual agreement basis. The utilization of feed stuffs by the respondents in order of greatest use in feeding their animals especially goats and sheep within their households were cassava peels, yam peels, grass, maize sievate, fried garri sievate, cassava leaf, plantain peels, cocoyam peels, banana peels, sweet potato leaf, rice offal and sweet potato peels.

Table 4 shows the estimates of farm animal population in a single and mixed herd owned by farmers in different households in the study area. The information from this table showed that the 80 farmers who reared their farm animals in single population kept an average of 3.04 (approximately 3) goats, 1.59 (approximately 2) sheep, 2.11 (approximately 2) fowls with little or no numbers of duck, pig and cattle by approximation. Similarly, for the 96 farmers that reared their farm animals in mixed populations the ratios were 9:4:6:0:0:0 for goats, sheep, fowls, duck, pig and cattle respectively by approximation considering real animal numbers per household.

Fig 1 and 2 shows a pictorial representation of the pattern of single and mixed farm ownership across the Local government areas in Cross River State investigated. 


\section{Discussion}

Farming activities (involving sole livestock and crop-livestock farming) in the area was observed to be an activity carried out by both male and females. However, the male folks were reported to be more involved than their female counterparts. This situation is similar to the results of the studies carried out by Odeyinka et al. (2009) in Ekiti State but in contrast to what was reported in Oyo State by Odeyinka and Okunade (2005), while investigating the level of participation of males and females in small ruminant production in these areas. Similarly, the complementary role played by the both sexes remains eminent in this study. It was observed that although the male farmers dominated the ownership of the farm animals, their female counterparts were much responsible for the care and management of the farm animals. Not only that they fed the animals, but also ensured their safety and good health (Fabusoro et al., 2007). The Raising of livestock was common among adults of 35-44 years age bracket representing a large percentage of the respondents. This age range was within the limits reported by Sodeinde et al. (2007) and Odeyinka et al. (2009) for farmers engaged in small ruminant livestock production. A reasonable number of the farming population interviewed during the survey comprised literate farmers who could at least read and write. This implies that the promotion of increased productivity of livestock and crop-livestock will be enhanced with the intervention of extension agents that can bring about better innovations and improve productivity (Sodeinde et al., 2007). Farmers in the villages to a large extent were involved in crop-livestock farming (Table 2). This is a worthwhile innovation, since crop-livestock integration is a common and efficient pathway for intensification of agriculture in developing countries as farmers have seen clear benefits from food-feed crops: human food, livestock feed, manure and draft power. In addition, they can also obtain cash income to purchase farm inputs, pay household expenses (food, health, education, etc.) as well as provide insurance during times of crisis and uncertainty (Thornton et al., 2002; Kristjanson et al., 2002). This can go a long way in improving their livelihoods. The predominant livestock management systems adopted by farmers were the semi-intensive and extensive systems, with very few farmers adopting the intensive system. This finding is in agreement with those of Adu and Ngere (1979), who reported that the bulk of the livestock farmers who raise their animals in most traditional village settings adopted the semi-intensive and extensive systems and that only in few cases are there animals managed intensively.

The types of livestock kept by the respondents in order of preference were goats, fowl, sheep, ducks, pigs and cattle. The high percentage of goat keepers recorded in the study was in agreement with the reports by ILCA (1980) which during a survey in South Western Nigeria indicated that over 70\% of the rural households in some villages kept goats. A greater proportion of the keepers of these livestock kept them in mixed populations, while others kept them in single populations, usually as sole owners of their farm animals, whereas very few own them on contractual agreement basis (Table 3). Sole ownership here implies that they had probably purchased these animals from both neighbouring local markets and government farms or received them as gifts (Odeyinka et al., 2009). The utilization of feed stuffs by the respondents in order of greatest use in feeding their animals especially goats and sheep within their households were cassava peels, yam peels, grass, maize sievate, fried garri sievate, cassava leaf, plantain peels, cocoyam peels, banana peels, sweet potato leaf, rice offal and sweet potato peels. However, the greater use of these crop by-products in the order stated above may be attributed to their ready availability and cheapness (Coleman and Moore 2003). Similarly, Onwuka, et al. (1997) has reported cassava peels, yam peels, banana peels and maize fermented wastes as most commonly fed household wastes to sheep and goats in Ogun State, Nigeria.

Table 4 shows the estimates of farm animal population in a single and mixed herd owed by farmers in different households in the study area. Livestock kept by farmers were kept in either single or mixed populations. Small ruminant farmers who rear either goats or sheep in single populations own an average of 3 and 2 of these animals respectively. This is in agreement with reports by Onwuka et al. (1997), who reported flock populations of 1- 4 and 1-3 for goats and sheep respectively. Similarly, for the mixed population the ratios were 9:4:6:0:0:0 for goats, sheep, fowls, duck, pig and cattle respectively per household. The goat numbers reported by farmers who kept them in mixed populations in this study were contrary to those reported by Ademosun (1987), who in his study reported average number of 5 goats per household. Fig 1 and 2 shows a pictorial representation of the pattern of single and mixed farm ownership across the Local government areas in Cross River State investigated.

\section{Conclusion and Recommendation}

The study observed that agro by-products abound in the rural villages of Cross River State that are not efficiently utilized by livestock farmers as potential feed resources for feeding their livestock. Crop-livestock systems which is advocated by most proponents of farming systems for developing countries is adopted but is weak in terms of practice, since the bulk of the farmers who adopt it are small-holder livestock farmers that adopt the semi-intensive and extensive management systems with very few flock of small ruminants. This animal numbers 
underutilize the feed stuffs allowing them lie waste and constitute a nuisance to the environment. It is therefore recommended that, the nutritional values of these feed stuffs be ascertained so as to be integrated into livestock feeding programmes. Furthermore, the intensive system of livestock production should be adopted where agro by-products via crop-livestock systems will properly utilize the untapped agro by-products. This will increase animal protein supplies, enhance better income generation and improve farmers' livelihoods in the area.

\section{References}

Adegbola, T.A, Ogbonna, R.C and Nwachukwu, N.E. (1988). Nutrient Intake, Digestibility and Rumen Studies inGoats fed varying levels of cassava peels and brewer's dried grain. Nigerian.Journal of Animal Production, (15): $161-166$.

Ademosun, A.A. (1987). Appropriate management systems for the West African Dwarf Goat in the humid tropics.In: O.B. Smith and H.G. Bosman (Eds). Goat production in the humid tropics. Proceedings of a worksho, $20^{\text {th }}-24^{\text {th }}$ July,University of Ife, Ile-Ife, Nigeria. (pp 21-28).

Adu, I.F. and Ngere, L.O. (1979). Indigenous sheep of Nigeria. World Rev, Proc.XV, pp 56-62.

Bawa, G.S., Abu, E.A. and Adegbulu, M.T. (2007). Effects of duration of cooking whole or crushed African Locust Bean (Parkia filicoidea, Welw) seeds on the levels of some anti-nutritional factors and growth performance of young rabbits. Nigerian.Journal of Animal Production, 34(2): 208 - 217.

Coleman, S.W. and Moore, J. E. (2003). Feed quality and animal performances. Field Crops Research, $84: 17-29$

Edache, J.A., Musa, U., Karsin, P.D., Esilonu, J.O., Yisa, A., Okpala, E.J. and Zwandor, N.J. (2007). The feeding value of cassava meal diets for growing Japanese Quail (Coturnix coturnix Japanica). Nigerian.Journal of Animal Production, 34 (1): 77 - 82.

El-Nouby, H.M. (1991). The role of by-products and Crop residues in SR production In: K.O. Adeniji (Ed). Proceedings of the Workshop on the improvement of Small Ruminants in North Africa, Cairo, Egypt 3-7, June, 1991. (pp189).

FAO. (1988). Food and Agriculture Organization of the United Nations. Production Year Book, Rome, Italy.

Fabusoro, E., Lawal-Adebowale, O.A and Akinloye, A.K. (2007). A study of rural livestock farmers' patronage of veterinary services for healthcare of small farm animals in Ogun State. Nigerian.Journal of Animal Production, 34 (1): 132 - 138.

Fasae, O.A., Adegoke, H.B., Ogunmekan, K.O. and Adu, I.F. (2007). Improving the feed utilization of cassava peels in smallholder goat production. Nigerian.Journal of Animal Production, 34(2): 251-257.

Kristjanson, P., Tarawali, S., Okike, I., Singh, B.B., Thornton, P.K., Manyong, V.M., Kruska, R.L., Hoogenboom, G. (2002). Genetically improved dual-purpose cowpea: assessment of adoption and impact in the dry savannah ofWest Africa. Impact Assessment Series No. 9. ILRI, Nairobi, Kenya, (pp67).

ILCA. (1980). ILCA the First Years, International Livestock Centre for Africa, Addis Ababa, Ethiopia.

Odeyinka, S.M., Ogunyebi, O.O. and Oyedele, O.J. (2009). Peri- Urban Small Ruminant feeding in Ekiti State. Nigerian.Journal of Animal Production, 36 (1): 96 - 101.

Odeyinka, S.M. and Ajayi, D.A. (2004). A survey of feedstuffs for goats in Osun State. Tropical. Journal of Animal Science, 7: 161-168.

Odeyinka, S.M., Okunnade, G.A. (2005). Goat production in Oyo State: A case study of Ogbomoso town. Nigerian.Journal of Animal Production, 32: 108 - 115.

Onwuka, C.F.I., Adetiloye, P.O. and Afolami, C.A. (1997). Use of household wastes and crop residues in small ruminant feeding in Nigeria. Small Ruminant Research, 24(1): 233-237

Sodeinde, F.G., Akinlade, V.O., Asaolu, V.O., Oladipo, M.A., Amao, S.R. and Alade, J.A. (2007). A survey of some Dry season feed materials for Small Ruminants in Ogbomoso, Nlgeria. Jourmal of Veterinary Advances, 6 (1): 142- 145.

Thornton, P.K., Krushka, R.L., Henninger, N., Kristjanson, P., Reid, R.S., Atieno, A.N., Ndegwa, T. (2002). Mapping Poverty and Livestock in the Developing World, ILRI, Nairobi, Kenya, 118pp. 
Table 1. Senatorial districts and the mode of distribution of questionnaires to respondents in villages randomly sampled

\begin{tabular}{|c|c|c|c|c|}
\hline $\begin{array}{l}\text { Senatorial } \\
\text { District }\end{array}$ & $\begin{array}{l}\text { Local } \\
\text { Government } \\
\text { Area }\end{array}$ & Villages sampled & $\begin{array}{l}\text { Questionnaire } \\
\text { Distribution }\end{array}$ & $\begin{array}{l}\text { Questionnaires } \\
\text { Retrieved }\end{array}$ \\
\hline $\begin{array}{ll}\text { Northern } & \text { Cross } \\
\text { River } & \end{array}$ & $\begin{array}{l}\text { 1.Ogoja } \\
\text { 2.Obudu }\end{array}$ & $\begin{array}{l}\text { Ogoja - Ishibori, } \\
\text { Nduk, Mbube West, } \\
\text { Emangkpa. } \\
\text { Obudu - Nkirira, } \\
\text { Ukorshie, Ukpriyi, } \\
\text { Ukambi. }\end{array}$ & $\begin{array}{l}1 \times 4 \times 8=32 \\
1 \times 4 \times 8=32\end{array}$ & 28 \\
\hline $\begin{array}{ll}\text { Central } & \text { Cross } \\
\text { River } & \end{array}$ & $\begin{array}{l}\text { 1.Obubra } \\
\text { 2.Ikom }\end{array}$ & $\begin{array}{lr}\text { Obubra- } & \text { Ofodua, } \\
\text { Iyamonyoung, Ogada } \\
\text { I, Ochon. } \\
\text { Ikom - } \\
\text { Ejibatun, } \\
\text { Nde. }\end{array}$ & $\begin{array}{l}1 \times 4 \times 8=32 \\
1 \times 4 \times 8=32\end{array}$ & 31 \\
\hline $\begin{array}{l}\text { Southern Cross } \\
\text { River }\end{array}$ & $\begin{array}{l}\text { 1.Biasse } \\
\text { 2.Akpabuyo }\end{array}$ & $\begin{array}{l}\text { Biase - Iwuru, } \\
\text { Betem, Akpet central, } \\
\text { Abini, } \\
\text { Akpabuyo-Idundu. } \\
\text { Ikot Edem 1ta, Ikot } \\
\text { Edem, Efut abua. }\end{array}$ & $\begin{array}{l}1 \times 4 \times 8=32 \\
1 \times 4 \times 8=32\end{array}$ & 30 \\
\hline Total & 6 & 24 & 192 & 176 \\
\hline
\end{tabular}

Table 2. General information on the Respondents

\begin{tabular}{|l|l|l|l|}
\hline Criterion & Response & No. of Respondents & Percentage \\
\hline \multirow{4}{*}{ Sex } & Male & 102 & 58.0 \\
\cline { 2 - 4 } & Female & 74 & 42.0 \\
\cline { 2 - 4 } & Total & $\mathbf{1 7 6}$ & $\mathbf{1 0 0}$ \\
\hline \multirow{5}{*}{ Age } & Below 24 years & 7 & 4.0 \\
\cline { 2 - 4 } & $25-34$ years & 49 & 27.8 \\
\cline { 2 - 4 } & $35-44$ years & 79 & 44.9 \\
\cline { 2 - 4 } & 45 years and above & 41 & 23.3 \\
\cline { 2 - 4 } & Total & $\mathbf{1 7 6}$ & $\mathbf{1 0 0}$ \\
\hline \multirow{5}{*}{$\begin{array}{l}\text { Sducation } \\
\text { farming }\end{array}$} & Illiterate & 99 & 56.2 \\
\cline { 2 - 4 } & Literate & 77 & 43.8 \\
\cline { 2 - 4 } & Total & $\mathbf{1 7 6}$ & $\mathbf{1 0 0}$ \\
\cline { 2 - 4 } & Sole livestock farming & 24 & 13.8 \\
\cline { 2 - 4 } & Crop/Livestock farming & 152 & 86.4 \\
\cline { 2 - 4 } & Total & $\mathbf{3 6 0}$ & $\mathbf{1 0 0}$ \\
\hline & Intensive & 10 & 5.7 \\
\cline { 2 - 4 } & Semi-intensive & 91 & 51.7 \\
& Extensive & 75 & 42.6 \\
\cline { 2 - 4 } & Total & $\mathbf{1 7 6}$ & $\mathbf{1 0 0}$ \\
\hline
\end{tabular}


Table 3. Farm animals, pattern/mode of ownership and agro by-products for animal feeding in different L.G.As of Cross Rivers State

\begin{tabular}{|c|c|c|c|}
\hline Criterion & Response & No. of Respondents & $\%$ \\
\hline \multirow[t]{7}{*}{ Type of farm animal kept } & Goat & 74 & 42.05 \\
\hline & Sheep & 33 & 18.75 \\
\hline & Fowl & 43 & 24.43 \\
\hline & Duck & 11 & 6.25 \\
\hline & Pig & 10 & 5.68 \\
\hline & Cattle & 5 & 2.84 \\
\hline & Total & 176 & 100 \\
\hline \multirow{3}{*}{$\begin{array}{l}\text { Pattern of keeping farm } \\
\text { animal in population }\end{array}$} & Single & 80 & 45.45 \\
\hline & Mixed & 96 & 54.55 \\
\hline & Total & 176 & 100 \\
\hline \multirow{3}{*}{$\begin{array}{l}\text { Mode of ownership of } \\
\text { farm animals }\end{array}$} & Sole ownership & 128 & 72.73 \\
\hline & Contractual agreement & 48 & 27.27 \\
\hline & Total & 176 & 100 \\
\hline \multirow{13}{*}{$\begin{array}{l}\text { Agro by-products used to } \\
\text { feed the farm animals }\end{array}$} & Cassava peel & 61 & 18.21 \\
\hline & Yam peel & 46 & 13.73 \\
\hline & Sweet potato peel & 13 & 3.88 \\
\hline & Maze sievate & 40 & 11.94 \\
\hline & Plantain peel & 21 & 6.27 \\
\hline & Banana peel & 17 & 5.07 \\
\hline & Cocoyam peel & 20 & 5.97 \\
\hline & Fried garri sievate & 27 & 8.06 \\
\hline & Grass & 40 & 11.94 \\
\hline & Cassava leaf & 22 & 6.57 \\
\hline & Sweet potato leaf & 15 & 4.48 \\
\hline & Rice offals & 13 & 3.88 \\
\hline & Total & 335 & 100 \\
\hline
\end{tabular}

Table 4. Estimates of farm animal population in a single and mixed herd owned by farm house hold in the L.G.As of Cross Rivers State investigated

\begin{tabular}{|c|c|c|c|c|c|}
\hline Criterion & $\begin{array}{l}\text { Total No. of } \\
\text { Respondents }\end{array}$ & Response & $\begin{array}{l}\text { Animal } \\
\text { population }\end{array}$ & $\begin{array}{l}\text { Average Animal } \\
\text { population per house } \\
\text { hold** }\end{array}$ & $\%$ \\
\hline \multirow{7}{*}{$\begin{array}{l}\text { Single farm animal } \\
\text { population }\end{array}$} & \multirow[t]{7}{*}{80} & Goat & 243 & 3.04 & 44.1 \\
\hline & & Sheep & 127 & 1.59 & 23.0 \\
\hline & & Fowl & 169 & 2.11 & 30.6 \\
\hline & & Duck & 12 & 0.15 & 2.2 \\
\hline & & Pig & 0 & 0.0 & 0.0 \\
\hline & & Cattle & 1 & 0.01 & 0.1 \\
\hline & & Total & 552 & 6.9 & 100 \\
\hline \multirow{7}{*}{$\begin{array}{l}\text { Mixed farm animal } \\
\text { population }\end{array}$} & \multirow[t]{7}{*}{96} & Goat & 881 & 9.18 & 41.6 \\
\hline & & Sheep & 469 & 4.89 & 22.2 \\
\hline & & Fowl & 610 & 6.35 & 28.8 \\
\hline & & Duck & 91 & 0.95 & 4.3 \\
\hline & & Pig & 34 & 0.35 & 1.6 \\
\hline & & Cattle & 32 & 0.33 & 1.5 \\
\hline & & Total & 2117 & 22.05 & 100 \\
\hline
\end{tabular}

* Average antmal populatton per house hold $=\frac{\text { Antmal populatton }}{\text { Total No, of Respondents }}$ 


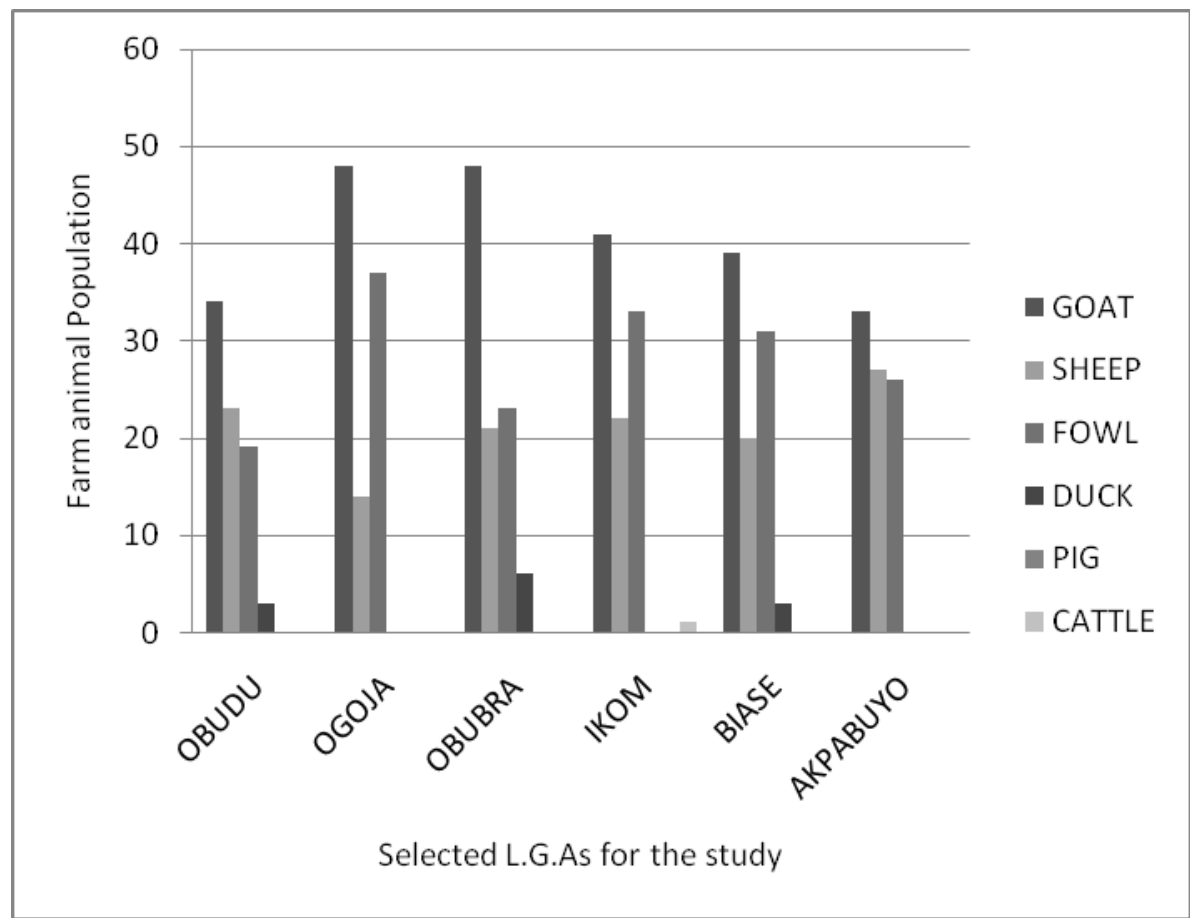

Figure 1. Pattern of single farm animal ownership by households across the L.G.As in Cross River State

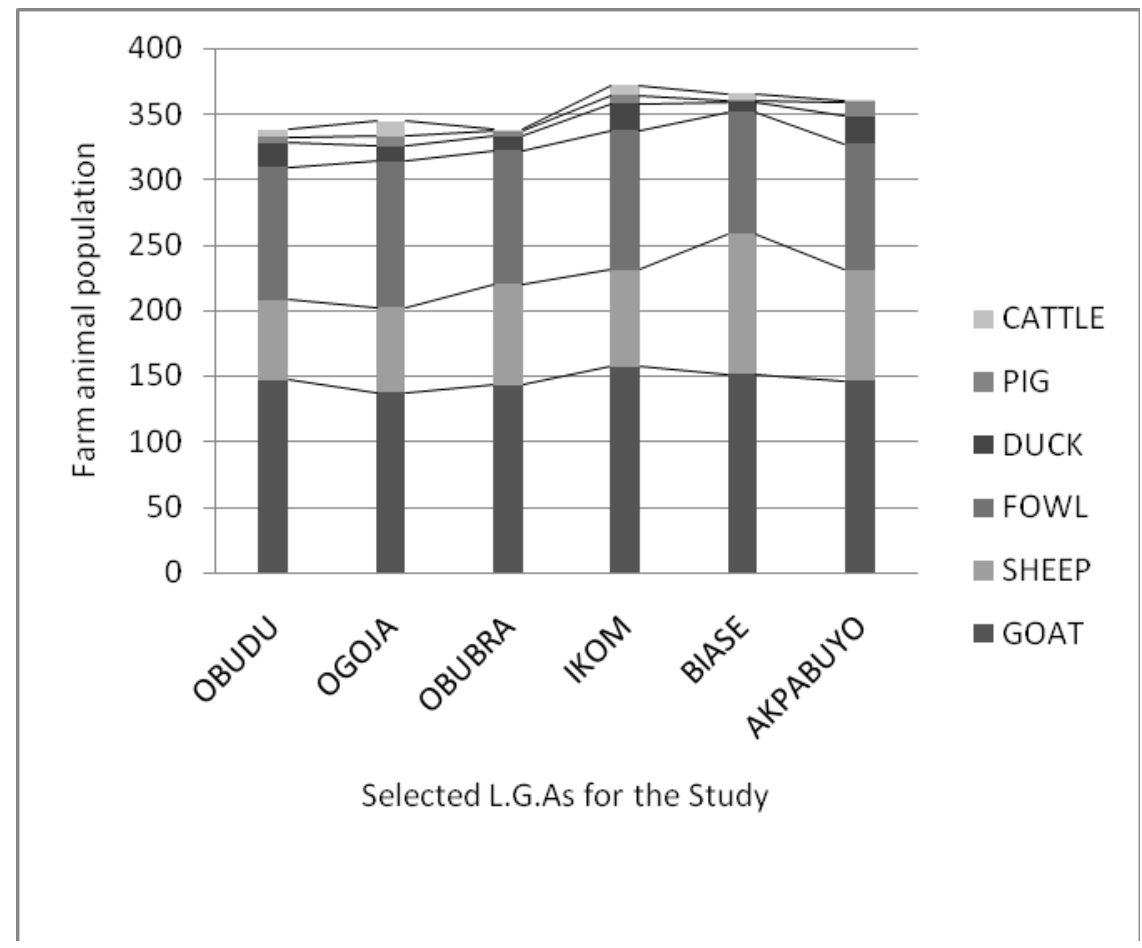

Figure 2. Pattern of mixed farm animal ownership by households across the L.G.As in Cross River State 